\title{
ANALIZA PODIZANJA VJETROZAŠTITNIH POJASA NA MEDITERANSKOM KRŠU HRVATSKE
}

\author{
ANALYSIS OF RAISING WINDBREAKS ON \\ THE MEDITERRANEAN KARST OF CROATIA
}

Damir BARČIĆ ${ }^{1}$, Vlado HABJANEC², Željko ŠPANJOL ${ }^{3}$, Mario ŠANGO4

\begin{abstract}
SAŽETAK
Vjetrozaštitni pojasi uspostavljaju se kao barijere od redova stabala ili grmlja koje se sade s namjenom reduciranja brzine vjetra, smanjenja evapotranspiracije, zaštite od eolske erozije, istovremeno izravno se koriste za zaštitu kultura i nasada te osiguravaju povoljnije stanišne uvjete. Jedna od bitnih pretpostavki uspjeha podizanja pojasa je korištenje autohtonih vrsta drveća i grmlja prilagođenih na stanišne uvjete. Tehnologije i postupci zaštite mogu biti usmjerene na biološko-tehničke postupke pošumljivanja i podizanja nasada s ciljem ublažavanja udara vjetra. Izbor biljnih vrsta za podizanje nasada uvjetovan je različitim klimatskim zonama, biološko-ekološkim značajkama vrsta, ali i kompoziciji s ostalim elementima krajobraza. Zaštita od vjetra postavlja se prema pravcu udara glavnog vjetra. Uspostava vjetrozaštitnih pojasa ponajprije smanjuje snagu vjetra i reducira njegovu brzinu. Na taj način ublažavaju se klimatski ekstremi povezani s olujnim vjetrom (na kršu se ponajprije radi o buri) i utječe na mikroklimatske uvjete, što u konačnici može osigurati zaštitu poljoprivrednog i šumskog zemljišta.
\end{abstract}

KLJUČNE RIJEČI: vjetar, propusnost, mikroklima, erozija, zaštita tla.

\section{UVOD}

\section{INTRODUCTION}

Vjetrozaštitni pojasi podižu se diljem svijeta, najčešće s ciljem zaštite poljoprivrednih površina (Brandle i dr. 2004, Campi i dr. 2009, Dostalek i dr. 2014). Uz navedeno, isti se mogu podizati i radi zaštite prometnica i naselja s ciljem smanjenja brzine vjetra i ublažavanja evapotranspiracije (Alemu, 2016). FAO (1989) definira vjetrozaštitne pojase kao barijere od redova stabala ili grmlja koje se sade s namjenom reduciranja brzine vjetra, smanjenja evapotranspiracije, zaštite od eolske erozije, istovremeno izravno se koriste za zaštitu kultura i nasada te osiguravaju povoljne mikroklimatske uvjete. Jedna od bitnih pretpostavki uspjeha podizanja pojasa je korištenje autohtonih vrsta drveća i grmlja koje su prilagođene na stanišne uvjete, ali i u krajobraznom smislu su prihvatljivije. Neke studije podupiru upravo autohtonu vegetaciju ukoliko je to moguće za podizanje pojasa (Rodwell i Patterson 1994, Farris i dr. 2010, Jelínek i Úradníček 2010). Na mediteranskom području krša u Hrvatskoj, iako postoji jak utjecaj vjetra od sjevernog do južnog dijela Jadrana, ne postoje intenzivna istraživanja posebno u području šumarstva. Navode se određeni problemi i lokaliteti kao što je Brač i sadnja 300.000 sadnica običnog čempresa za burobrane u razdoblju od 1933. do 1935. godine (Beltram, 1949). Isti autor navodi i pošumlja-

\footnotetext{
1 izv. prof. dr. sc. Damir Barčić, Sveučilište u Zagrebu Fakultet šumarstva i drvne tehnologije, Svetošimunska 25, Zagreb, dbarcic@sumfak.hr ${ }^{2}$ Vlado Habjanec, mag. ing. silv., Jačkovina 101, Zagreb, vlado.habjanec@gmail.com

${ }^{3}$ prof. dr. sc. Željko Španjol, Sveučilište u Zagrebu Fakultet šumarstva i drvne tehnologije, Svetošimunska 25, Zagreb, zespanjol.rab@gmail.com

${ }^{4}$ Mario Šango, dipl. ing. šum., Sveučilište u Zagrebu Fakultet šumarstva i drvne tehnologije, Svetošimunska 25, Zagreb, msango@sumfak.hr
} 
vanje na pruge s ciljem ublažavanja utjecaja vjetra, uz napomenu kako je cilj sklapanje tih pruga u šumske komplekse. Taj način pošumljavanja na pruge koristio se i ranije na području Senjske drage. Radi zaštite poljoprivrednih površina postoje projekti koji su do sada napravljeni i istraživani (Tomašević, 1996) na području Sinjskog polja i (Kisić i dr. 2013; Kisić, 2017) na području Čepić polja. Oni ukazuju na poboljšavanje mikroklimatskih uvjeta koje stvaraju vjetrozaštitni pojasi. Istovremeno zanemarena je činjenica da korištenje i podizanje takvih pojasa pozitivno utječe i na šumsko zemljište (Aussenac, 1999). Istraživanja u tom smislu navode smanjenje solarne radijacije, što ima učinak na poboljšanje mikroklimatskih i edafskih uvjeta (Cannell i Grace, 1993; Berbiger i Bonnefond 1995; Hassika i dr. 1997). S obzirom na izražene procese degradacije i devastacije na mediteranskom kršu uspostava pojasa je tehnički i biološki zahtjevna, jer se radi o problemu izbora vrsta, dimenzioniranju pojasa i mjerama održavanja vrsta tijekom formiranja pojasa. Unatoč navedenom, njihova uloga može imati više prednosti i pozitivno utjecati za zaštitu šuma i šumskog zemljišta na kršu.

\section{CILJ ISTRAŽIVANJA}

U radu će se analizirati glavni čimbenici koji utječu na nastanak štetnog djelovanja vjetra. Bit će prikazane posljedice djelovanja vjetra, glavni razlozi podizanja i osnivanja vjetrozaštitnih pojasa i nasada, način funkcioniranja vjetrozaštitnih pojasa, uvjeti izrade plana podizanja pojasa i nasada. Analizirat će se i interpretirati potreba zaštite od štetnog djelovanja vjetra i njihova opravdanost.

\section{PODRUČJE ISTRAŽIVANJA FIELD OF RESEARCH}

Istraživano područje vezano je uz mediteranski dio dinarskog krša Hrvatske. Na području krških polja veće su potrebe radi zaštite poljoprivrednog zemljišta. U novije vrijeme više se ističe i uspostava vjetrozaštitnih pojasa radi zaštite prometnica.

\section{REZULTATI \\ RESULTS}

Tehnologije i postupci zaštite mogu biti usmjerene na biološko-tehničke postupke pošumljivanja i podizanja nasada s ciljem ublažavanja udara vjetra. Cilj vjetrobranih pojasa i podizanje nasada s različitim vrstama drveća i grmlja prikazan je na slikama (slike 3,4,5,6,7). Izbor biljnih vrsta za podizanje nasada uvjetovan je različitim klimatskim zonama, biološko-ekološkim značajkama vrsta, ali i kompoziciji s ostalim elementima krajobraza. Zaštita od vjetra postavlja se prema pravcu udara glavnog vjetra. Važna značajka vjetrozaštitnih pojasa je njihova propusnost za vjetar i utjecaj na brzinu vjetra. Propusnost ovisi o habitusu biljke, te vrsti drveća i grmlja. Gustoćom vjetrobranog pojasa mijenja se njegov utjecaj i djelotvornost; propustan pojas osigurava uravnoteženu raspodjelu jer ga dio vjetra preskače, a dio prolazi kroz pojas. Ukoliko je vjetrobrani pojas pregust, vjetar prelazi preko pojasa što stvara uvjete za zonu niskog tlaka u zavjetrini, a potom i pojavu vrtloženja (turbulencija) i smanjenu zonu zaštite. U pravilu bitno je da vjetrozaštitni pojas bude okomit na udar dominantnog vjetra uz odstupanja do $30^{\circ}$. Izvedba vjetrozaštitnih pojasa može biti nepropusna, polupropusna i propusna.

Ključna napomena odnosi se na rezultate istraživanja na ravničarskom terenu koje treba s velikom rezervom i korekcijom prenijeti na krški teren, jer njega karakteriziraju raznolikosti u geomorfološkim i reljefnim obilježjima.

Kod podizanja vjetrozaštitnih pojaseva osnovni cilj je:

1. za koliko pojedine zapreke smanjuju ili ublažavaju snagu vjetra

2. na kojoj udaljenosti djeluje to smanjenje snage vjetra

Tehnički postupci zaštite od vjetra obuhvaćaju izgradnju prepreka od građevinskih materijala poput opeke, kamena, drvne građe, stakla, tvrde plastike ili kombinacijom više vrsta materijala. Tehnički oblici zaštite (Slike 1 i 2 ) od vjetra imaju prednost zbog brzine ugradnje i po potrebi $100 \% \mathrm{gu}-$ stoće koja zaustavlja udare vjetra i smanjuje štetno djelovanje vjetra. Nedostaci tehničkog oblika zaštite su visoka cijena i estetika.

Biološki postupci u smislu izbora vrsta i uvažavanja stanišnih uvjeta puno su kompleksniji. Sve to u kontekstu česte promjene "strukture vjetra" na krškom području. Osim ("advektivnog") laminarnog horizontalnog kretanja zračnih masa, na krškom neravnom području postoji i ("konveksno") turbulentno strujanje. Osim toga kod bure

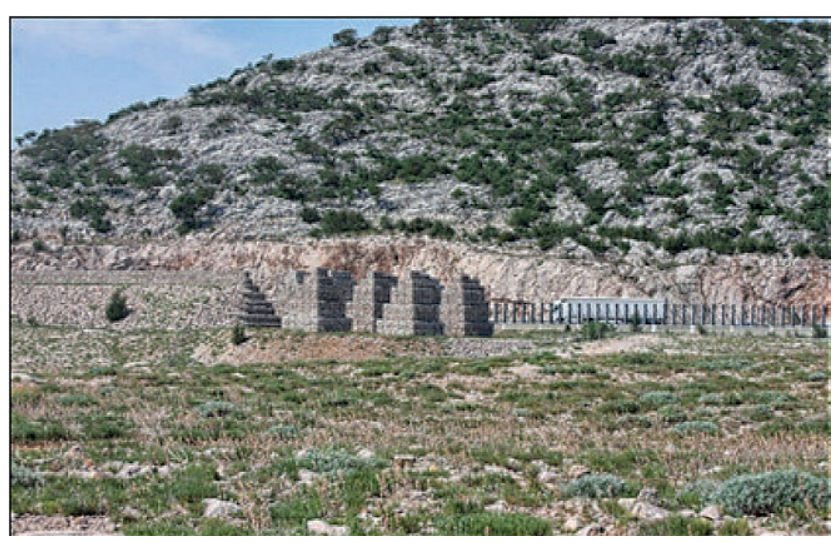

Slika 1. Tehnički oblici zaštite na dijelu autoceste od sv. Roka do Maslenice

Figure 1 Technical forms of protection on the part of the highway from Sv. Rok to Maslenica (Foto: D. Barčić) 


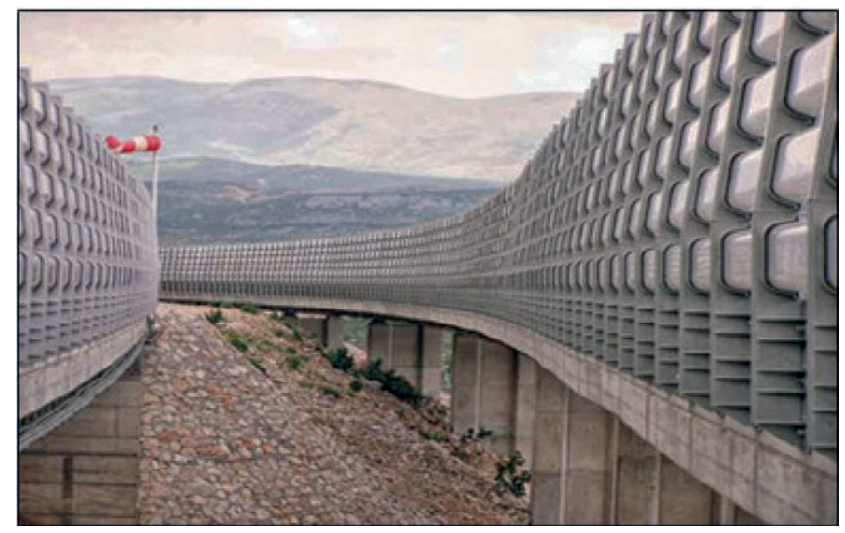

Slika 2. Tehnička zaštita uz autocestu

Figure 2 Technical protection on highway (lzvor: http://polirol.com/ u Habjanec (2020))

je važno obilježje njeno puhanje na mahove, gdje u kratkom razdoblju od par minuta može biti brzine nekoliko $\mathrm{km} / \mathrm{h}$, da bi za tren dobili udar bure od 100 i više $\mathrm{km} / \mathrm{h}$. Tu je još i raznolikost reljefa, posebno planinski lanci duž Jadranske obale Kapela, Velebit, Dinara, Biokovo i pedomorfoloških obilježja (uvale, škrape, visoke stijene, usjeci, vrtače, dolci i dr.) koji u mnogome utječu na smjer vjetra u makro i mikro lokacijama. Podizanje pojasa može se razlikovati prema namjeni i očekivanom učinku na sljedeći način:

\section{Nepropusni pojas}

Nepropusni ili slabo propusni pojas podiže se od zimzelenog ili listopadnog drveća i grmlja, pri čemu u vertikalnom profilu otvori u pojasu ne prelaze 5\% propusnosti (slike 3 i 4). Ovaj tip pojasa zračne struje prolaze preko vrhova stabala velikom brzinom. Neposredno iza pojasa stvara se zavjetrina, ona je vrlo kratka i iza nje se javlja tzv. zračni valjak; horizontalni vihor. Tu se stvaraju turbulencije i zaštita od vjetra je na kratkoj udaljenosti od pojasa. U pravilu nepropusni pojasevi se podižu radi bržeg rasta i brzog postavljanja u funkciju.

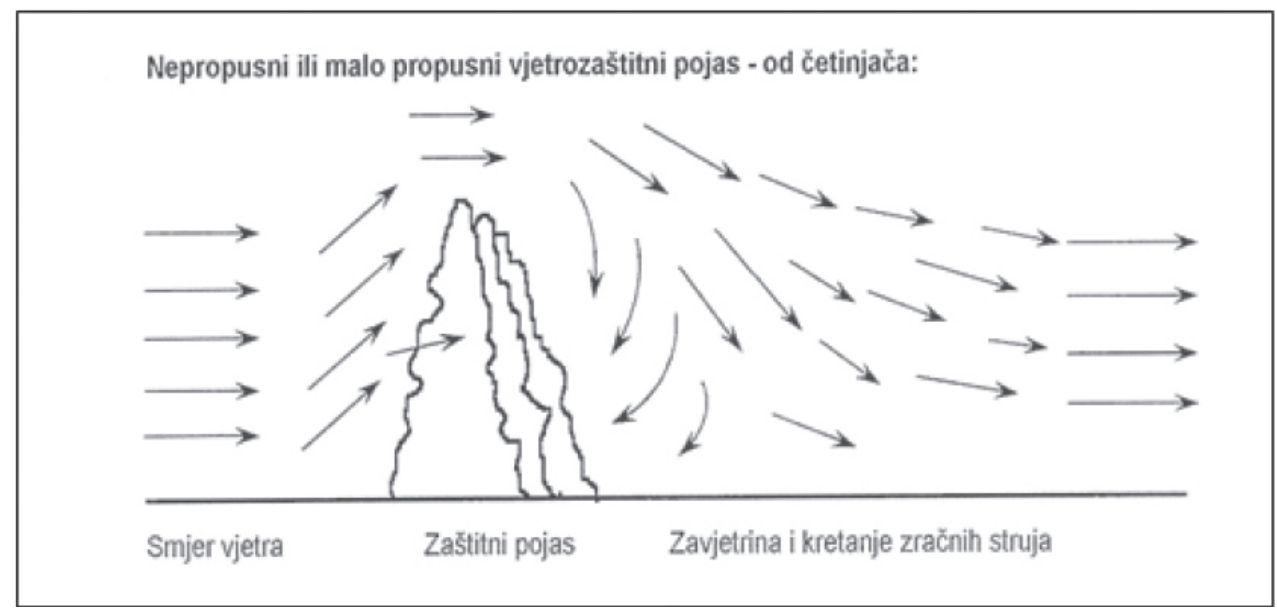

Slika 3. Prikaz nepropusnog ili slabo propusnog pojasa od četinjača

Figure 3 Display of impermeable or poorly permeable belt from conifer (Izvor: Španjol, Barčić, Šango 2019 (korigirano prema Tomašević 1996))

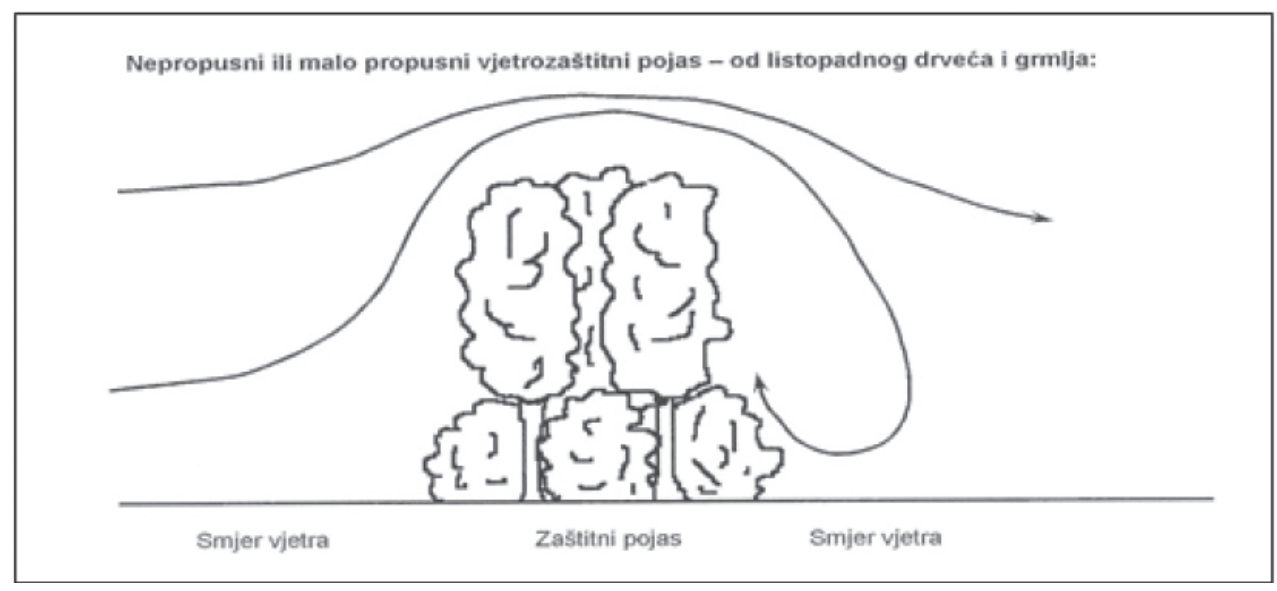

Slika 4. Prikaz nepropusnog ili slabo propusnog pojasa od listopadnih vrsta

Figure 4 Display of impermeable or poorly permeable belt of deciduous species (Izvor: Španjol, Barčić, Šango 2019 (korigirano prema Tomašević 1996)) 


\section{Polupropusni pojas}

Osnovne značajke polupropusnog pojasa su vezane uz podjelu zračnih struja u dva smjera. Jedan dio struja prelazi preko vrha pojasa, a drugi dio prolazi kroz pojas i djeluje kao aerodinamička rešetka (slike 5 i 6). Strujanje kroz pojas odbacuje vihor, zračni valjak koji se stvara na zavjetrinoj strani slabi i spušta se prema tlu na većoj udaljenosti u odnosu na nepropusni pojas.

\section{Propusni pojas}

U propusnom pojasu zračne mase, strujanje prolazi većom brzinom između stabala i krošanja drveća. Strujanje zračnih masa se povećava, a brzina vjetra se usporava (slika 7). Ovo strujanje odbacuje vihor, zračni valjak od površine tla. Propusni pojasevi osiguravaju najveću širinu područja zaštićenog utjecaja.
U zoni postavljanja vjetrobranog pojasa od $200 \mathrm{~m}$ (slike $8 \mathrm{i}$ 9) na mediteranskom kršu, sredinom pojasa prolazi protupožarna cesta (širine 10m). Razmak između pojasa je $10 \mathrm{~m}$. Unutar razmaka između pojasa od $10 \mathrm{~m}$ ostavlja se zeleni; zatravljeni dio s eventualnom sadnjom smilja. Razmak sadnica u prvom redu pojasa je 3x3 metra, a gustoća sadnje 3333 sadnice po hektaru. Omjer sadnog materijala je $60 \%$ crnoga bora, $20 \%$ alepskog bora i $20 \%$ primorskog bora. Razmak sadnica u drugom redu pojasa je $2 \times 2$ metra, a gustoća sadnje 5000 sadnica po hektaru. Omjer sadnog materijala je 35\% običnog čempresa i $35 \%$ arizonskog čempresa, te po $10 \%$ koprivića, crnog jasena i maklena. Razmak sadnica u trećem redu petorednog pojasa je 1,5x1,5 metara, a gustoća sadnje je 6.666 sadnica po hektaru. Omjer sadnog materijala je $40 \%$ primorske somine i $40 \%$ lovora, te $20 \%$ brnistre. U trorednom pojasu razmaci sadnje u prvom i drugom redu su isti, a razlika je u trećem redu gdje je razmak $2 \times 2$ metra.

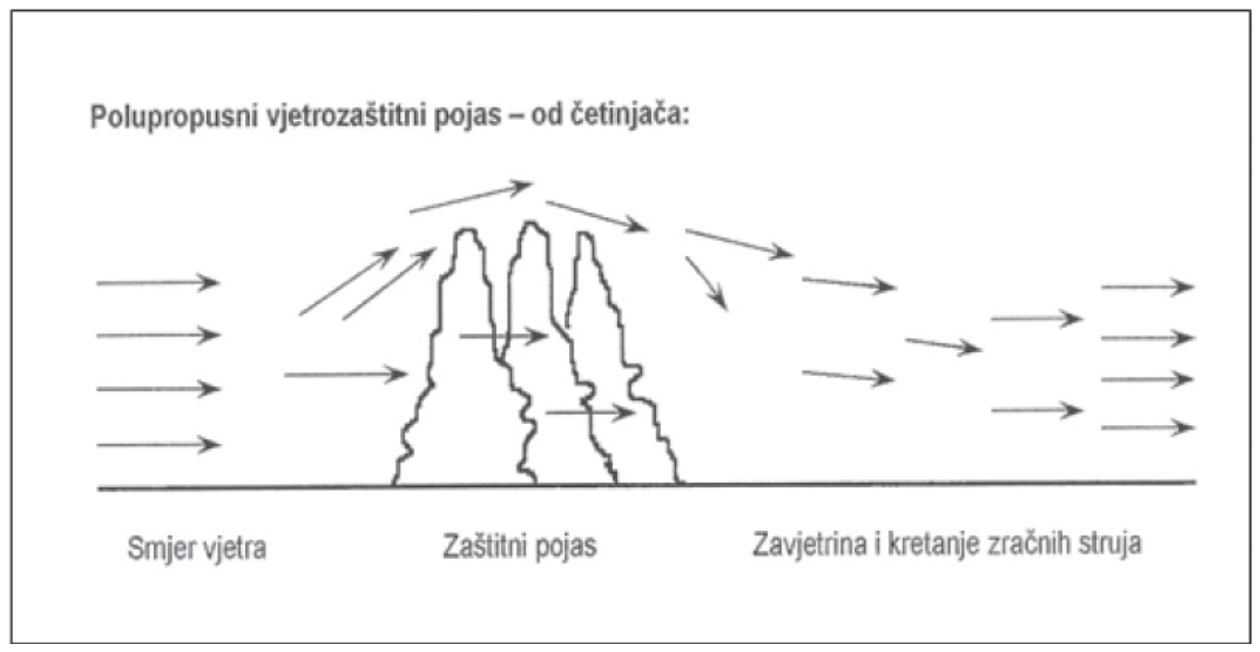

Slika 5. Prikaz djelovanja zračnog strujanja na polupropusni pojas četinjača

Figure 5 Display of the effect of air flow on a semi-permeable belt of conifers (Izvor: Španjol, Barčić, Šango 2019 (korigirano prema Tomašević 1996))

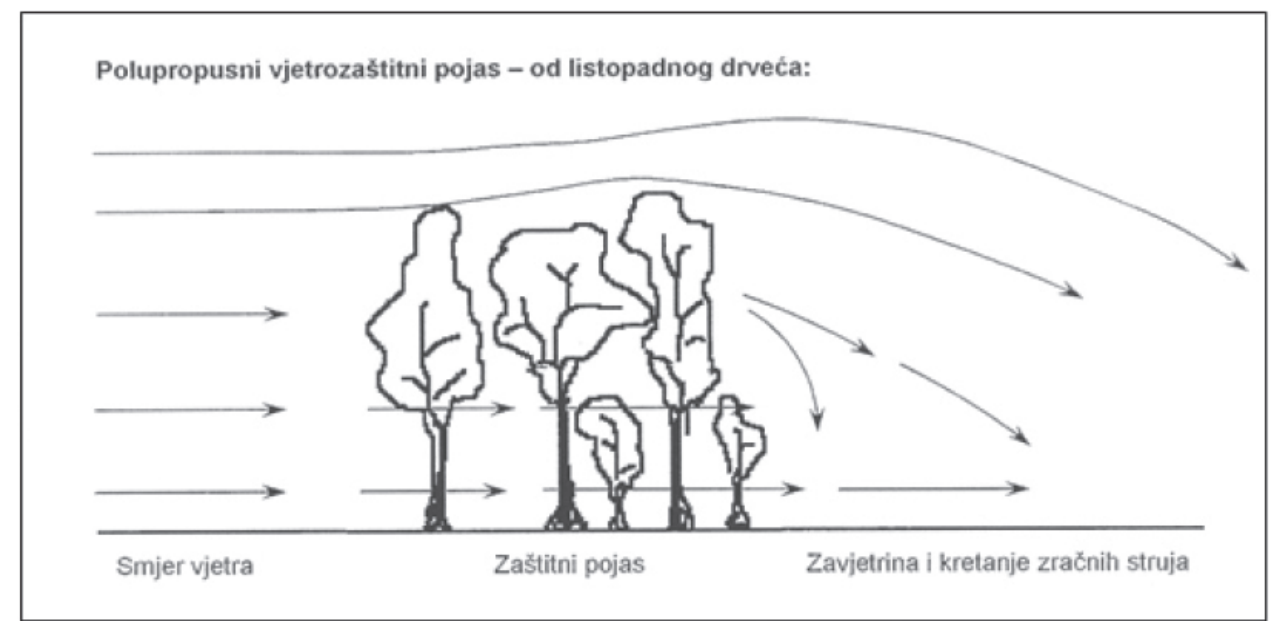

Slika 6. Prikaz djelovanja zračnog strujanja na polupropusni pojas listopadnih vrsta

Figure 6 Display of the effect of air flow on the semipermeable belt of deciduous species (Izvor: Španjol, Barčić, Šango 2019 (korigirano prema Tomašević 1996)) 


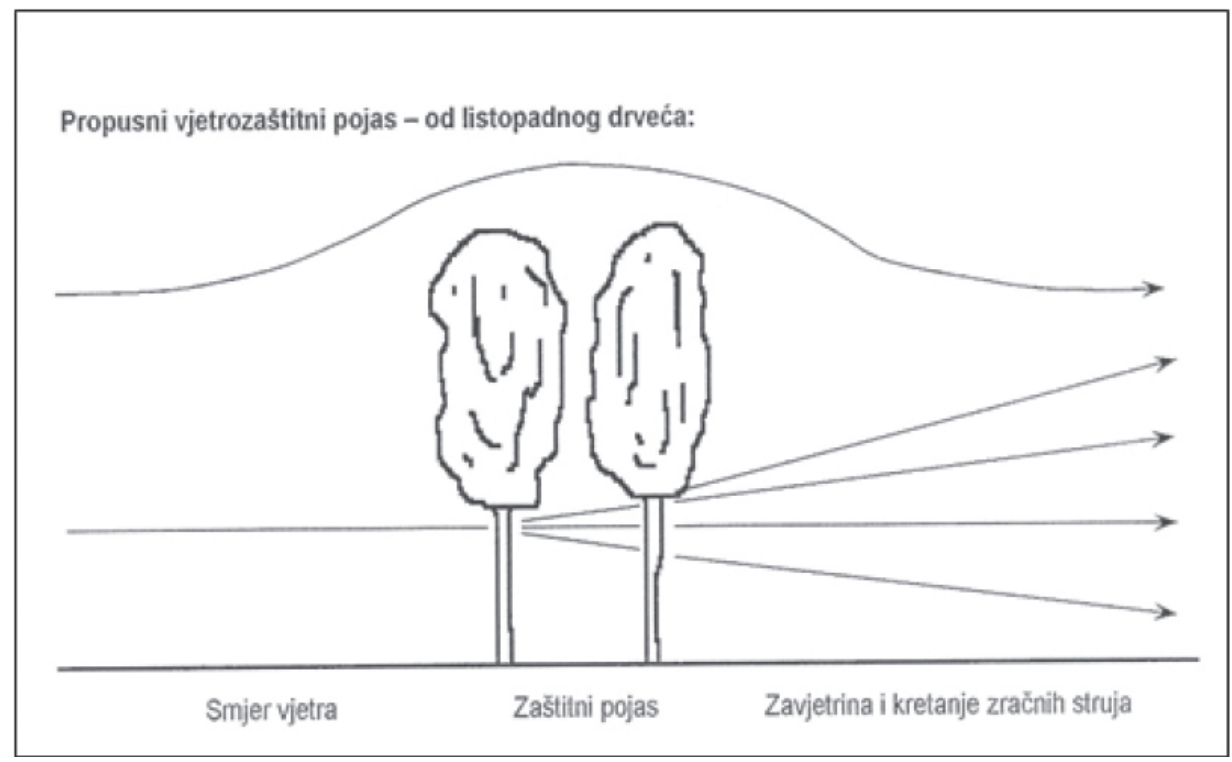

Slika 7. Propusni vjetrozaštitni pojas od listopadnog drveća

Figure 7 Permeable windbreak of deciduous trees (Izvor: Španjol, Barčić, Šango 2019 (korigirano prema Tomašević 1996))

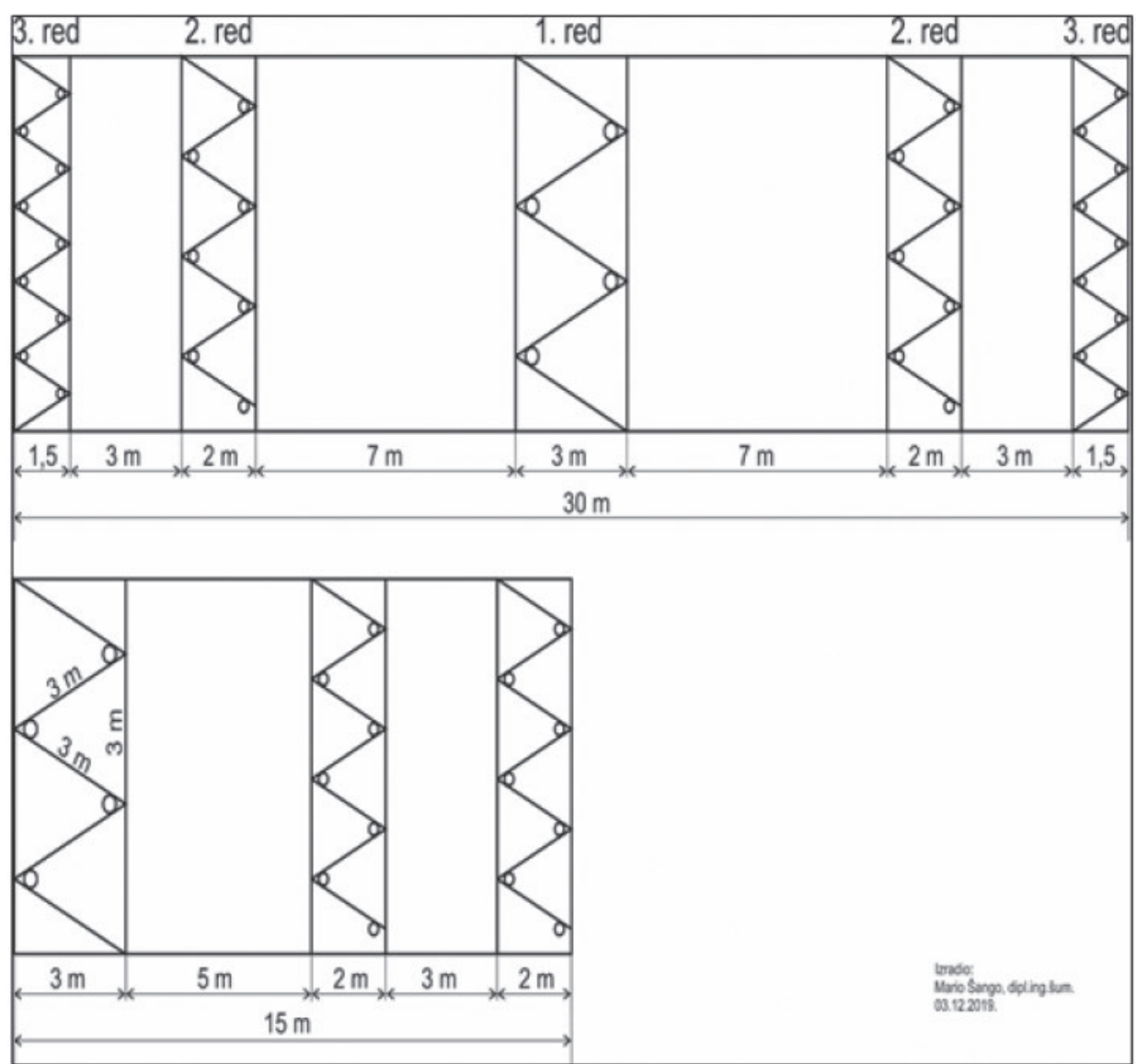

Slika 8. Razmaci i plan postavljanja vjetrobranih pojasa (petoredni i troredni pojas)

Figure 8 Spacing and windbreak installation plan (five-row and three-row belt

Prema Tomaševiću (1996) i dosadašnjim iskustvima na udaljenosti 25 visina od pojasa postižu se procijenjeni postoci brzine vjetra (Tablica 2). Iz navedenog proizlazi da je brzina vjetra više reducirana što je kut upada veći. Osim toga, bitan podatak je i visina pojasa (Tablica 1), jer je u korelaciji s dužinom površine koju se štiti. Upravo na taj način ispunjava se cilj pojasa koji ublažava udar vjetra i smanjuje brzinu. 


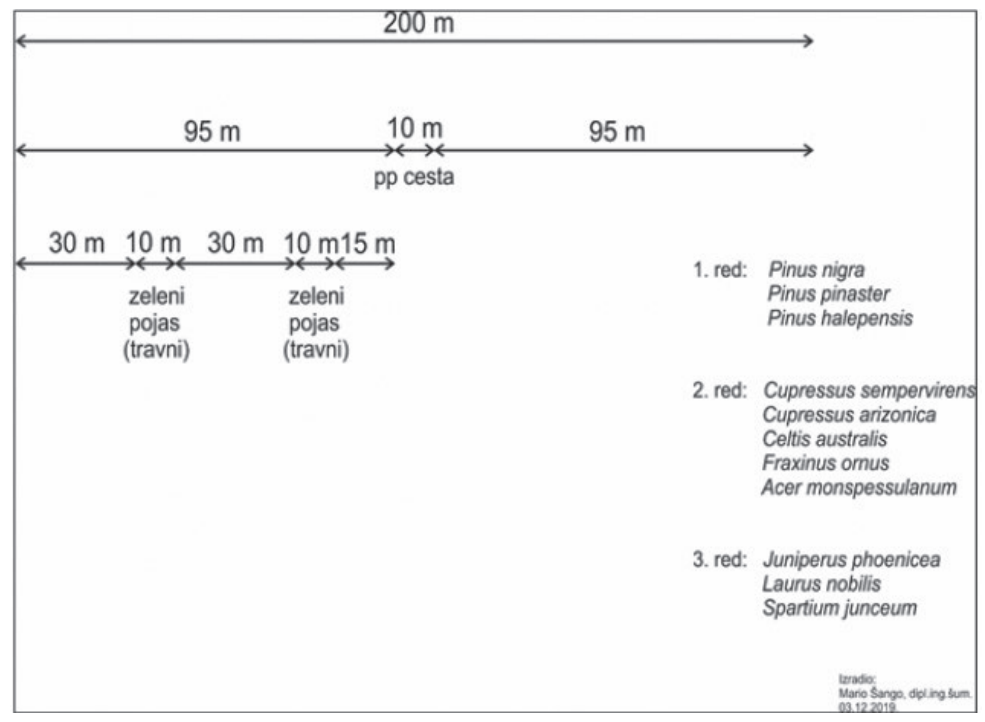

Slika 9. Širina i raspored u vjetrozaštitnom pojasu

Figure 9 Protective belt width and arrangement of windbreaks

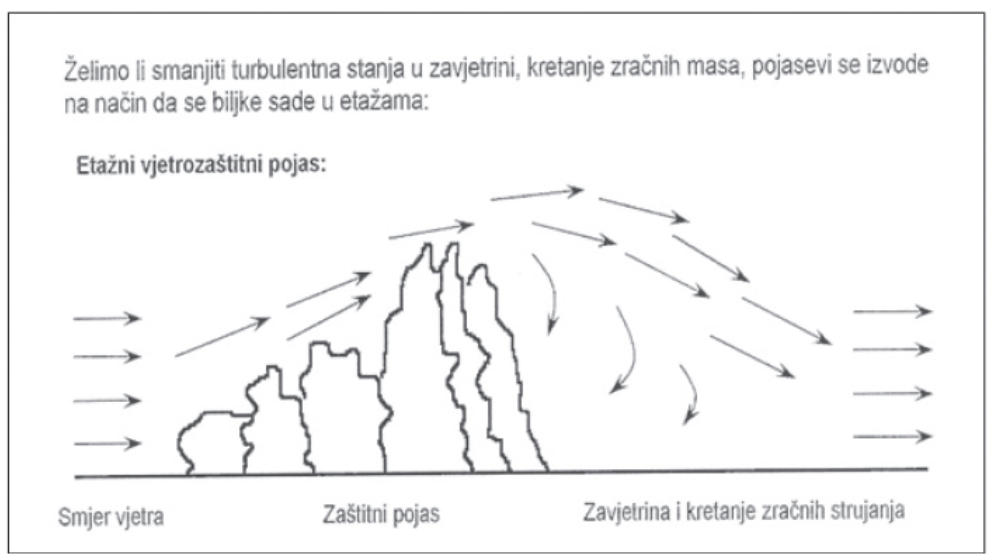

Slika 10. Etažni ili visinski vjetrozaštitni pojas

Figure 10 Height windbreaks (Izvor: Španjol, Barčić, Šango 2019 (korigirano prema Tomašević 1996))

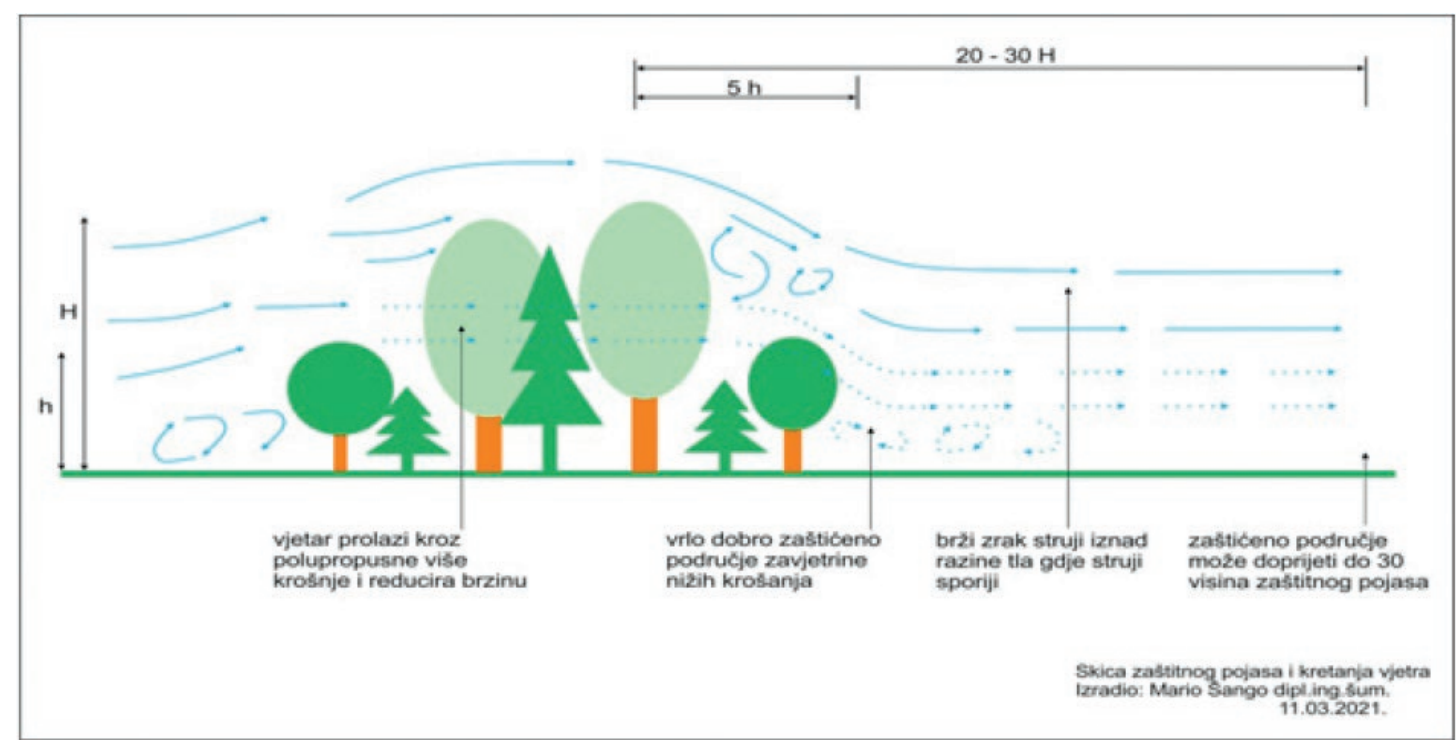

Slika 11. Vjetrozaštitni pojas i strujanje vjetra

Figure 11 Windbreak and wind current 


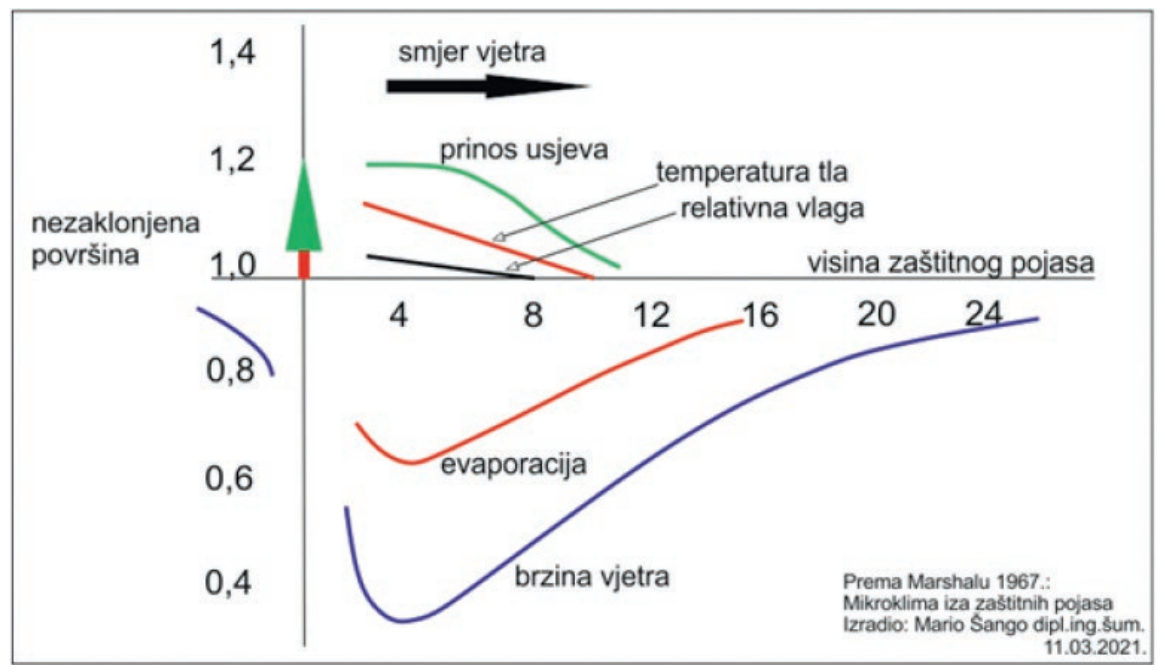

Slika 12. Utjecaj vjetrozaštitnog pojasa na mikroklimu

Figure 12 Influence of windbreak on microclimate

Tablica 1. Visina zaštitnog pojasa i dužina zaštitne površine prema gore navedenom izračunu

Table 1 Protective belt height and protective surface length according to the above calculation

\begin{tabular}{|cc|}
$\begin{array}{c}\text { Visina zaštitnog pojasa } \\
\text { Protective belt height }\end{array}$ & $\begin{array}{c}\text { Dužina zaštićene površine } \\
\text { Protective surface length }\end{array}$ \\
\hline $3,0 \mathrm{~m}$ & $22,5 \mathrm{~m}$ \\
$5,7 \mathrm{~m}$ & $81,2 \mathrm{~m}$ \\
$6,0 \mathrm{~m}$ & $90,0 \mathrm{~m}$ \\
$9,0 \mathrm{~m}$ & $202,5 \mathrm{~m}$ \\
\hline
\end{tabular}

Tablica 2. Odnos kuta upada vjetra i postotka brzine vjetra Table 2 The ratio of the wind angle and the percentage of the wind speed

\begin{tabular}{|c|c|}
\hline \multicolumn{2}{|c|}{$\begin{array}{l}\text { Udaljenost } 25 \text { visina od pojasa } \\
\text { Distance } 25 \text { height from the belt }\end{array}$} \\
\hline $\begin{array}{l}\text { Kut upada vjetra } \\
\text { Wind angle }\end{array}$ & $\begin{array}{c}\text { Postotak brzine vjetra } \\
\text { Percentage of the wind speed }\end{array}$ \\
\hline $90^{\circ}$ & $54 \%$ \\
\hline $68^{\circ}$ & $63 \%$ \\
\hline $45^{\circ}$ & $80 \%$ \\
\hline $23^{\circ}$ & $95 \%$ \\
\hline
\end{tabular}

\section{RASPRAVA DISCUSSION}

Vjetar je abiotski čimbenik, koji svojim djelovanjem i svojom razornom snagom bitno mjenja funkcioniranje ekosustava i obavljanje ljudskih djelatnosti. Vjetar nema samo negativo djelovanje na ekosustave. Pozitivni utjecaj vjetra u ekosustavima se ogleda u filtriranju i miješanju zraka, isušivanju zamočvarenih površina, raznošenju sjemena biljaka, prirodnoj obnovi šumskih ekosustava. Vjetar je neophodna sastavnica svakog ekosustava, ali vjetar se razlikuje svojom jačinom, snagom, svojim naletima i udarima pa različite vrste vjetrova različito utječu na ekosustave, ali i na obavljanje ljudskih djelatnosti. Strujanje zraka nad nekim područjem odraz je primarne cirkulacije koja se uspostavlja globalnom raspodjelom tlaka zraka značajnom za topli i hladni dio godine. Međutim, promjene tlaka zraka makrorazmjera i u kraćim razdobljima generiraju sekundarnu cirkulaciju. To su pokretni cirkulacijski sustavi koji uzrokuju lokalne vjetrove različitih značajki ovisno o reljefu tla, svojstvima podloge i zračnih masa. Isto tako postoje i cirkulacije srednjih i lokalnih razmjera koje su posljedica periodičke termičke promjene zbog lokalnih karakteristika terena (Bajić, 2003). Posljedice štetnog djelovanja vjetra nagnale su ljude da zaštite prirodne ekosustave, svoje domove, izvore prihoda, poljoprivredne površine i ostala područja i objekte koji mogu pretrpjeti štetu izazvanu vjetrom. Takvo štetno djelovanje vjetra dovelo je do osnivanja i podizanja vjetrozaštitnih pojasa i nasada. Prvi vjetrozaštitni pojasevi podizani su uz poljoprivredne površine kako bi se zaštitili usjevi od štetnog djelovanja vjetra. Prvi zapisi o vjetrozaštitnim pojasima spominju se u Škotskoj sredinom 14. Stoljeća, kada je škotski parlament urgentnim planom naredio podizanje vjetrozaštitnih pojasa kako bi se zaštitila agrikulturna proizvodnja (Brandle, 2009). Poljoprivredne površine trpe najteže gubitke izazvane jakim i olujnim vjetrovima, ali stradati mogu i šumski ekosustavi te može biti ugrožena njihova obnova. Postoje i druge površine i objekti koji stradavaju od olujnog vjetra ili su u nemogućnosti obavljanja primarnih funkcija poput šumskih rasadnika i različitih proizvodnih objekata i površina. Posebno je jak utjecaj olujnog vjetra na promet $i$ to na različitim vrstama prometnica (autoceste, županijske ceste i dr.). Postoje tehnički i biološki postupci zaštite od vjetra. Tehnički postupci zaštite od vjetra obuhvaćaju izgradnju prepreka od građevinskih materijala poput opeke, kamena, drvne građe, stakla, tvrde plastike ili kombinacijom više 
vrsta materijala. Tehnički oblici zaštite od vjetra imaju prednost zbog brzine ugradnje i velike gustoće koja u potpunosti ili velikim dijelom zaustavlja udare vjetra i smanjuje štetno djelovanje vjetra. Nedostaci uporabe tehničkog oblika zaštite su ponajprije cijena i estetika. Biološki oblik zaštite i podizanje zaštitnih pojasa s različitim vrstama drveća i grmlja nije nimalo jednostavan zadatak, potrebno je uzeti u obzir prirodne zakonitosti, ekološke i klimatske zahtjeve. Nadalje, voditi računa o konfiguraciji terena, geografskim, geološkim i pedološkim obilježjima lokaliteta na kojemu se podiže vjetrozaštitni pojas. Podizanje vjetrozaštitnih pojaseva ne smije se raditi bez dugoročnog promišljanja i razrade mogućih utjecaja, stoga taj posao treba prepustiti stručnim osobama različitih struka poput šumarske, agronomske, prometne i ostalih struka koje se prepoznaju u poslovima podizanja vjetrozaštitnih pojasa i nasada (Kisić, 2013).

Podignuti vjetrozaštitni pojasi i nasadi ne mogu odmah u potpunosti ispunjavati sve očekivane funkcije, već se provođenjem njege, zaštite i ostalih metoda usmjerava rast $\mathrm{i}$ razvoj takvih pojasa, kako bi što svrsishodnije ispunjavali sve funkcije i opravdali očekivanja. Uz navedeno, potrebno je uključiti mjere održavanja i praćenja stanja radi pravovremenog djelovanja u slučaju potrebe. Dimenzioniranje zaštitinih pojasa ovisi o konkretnoj situaciji na terenu, a glavni elementi su visina, širina, dužina i gustoća pojasa. Ti elementi su u korelaciji s kutom upada vjetra, brzinom vjetra, intenzitetu vjetra, konfiguraciji terena, izloženosti, tipu tla i pedomorfološkim karakteristikama, te položaju već izgrađenih objekata ako se radi o zaštiti prometnica. Kod vjetrozaštitnih pojasa razlikujemo glavni pojas i sporedni pojas. Glavni pojas postavlja se okomito na pravac najjačeg vjetra, a sporedni okomito na glavni pojas. Na taj način sprječavamo turbulenciju sa strane i negativno djelovanje vjetrova koji se javljaju iz drugih smjerova (Tomašević, 1996). Za učinkovitost pojasa u uvjetima mediteranskog krša uvažavajući bioklimatski i edafski gradijent korisna bi bila primjena navodnjavanja, dovoženja zemlje, prignojavanja i uključenje elemenata zaštite bilja i zaštite od požara.

\section{ZAKLJUČAK CONCLUSION}

Uspostava vjetrozaštitnih pojasa ponajprije smanjuje snagu vjetra i reducira njegovu brzinu. Na taj način ublažavaju se klimatski ekstremi povezani s olujnim vjetrom (na kršu se ponajprije radi o buri) i utječe na mikroklimatske uvjete, što u konačnici može osigurati zaštitu poljoprivrednog i šumskog zemljišta. Stoga se mogu navesti sljedeće prednosti: zaštita i ublažavanje eolske erozije, zaštita od posolice, povoljan utjecaj na zračnu vlagu i akumulaciju vlage u tlu, smanjuje se isušivanje i evapotranspiracija, zaštita prometnica i naselja. Nedostaci mogu biti više izraženi na poljo- privrednim površinama radi smanjenja proizvodne površine, postavljanje pojasa u blizini sustava za navodnjavanje i odvodnju može utjecati na oštećenja kanalske mreže i drenažnih cijevi, zatim povećani troškovi uspostave pojasa u slučaju kada dođe do pogrešnog odabira vrsta. Zasigurno bi izgled i kompozicija pojasa trebala biti usklađena s elementima krajobraza. U razradi i projektnoj dokumentaciji potrebno je uzeti u obzir primjenu tehnologija koje u uvjetima mediteranskog krša osiguravaju učinkovita rješenja.

\section{LITERATURA}

\section{REFERENCES}

- Alemu, M.M. 2016: Ecological Benefits of Trees as Windbreaks and Shelterbelts. International Journal of Ecosystem 6 (1): 1013. doi: $10.5923 /$ j.ije.20160601.02

- Aussenac, G., 2000: Interactions between forest stands and microclimate: Ecophysiological aspects and consequences for silviculture. Ann. For. Sci. (57) 287-301. doi:10.1051/forest:2000119

- Bajić, A., 2003: Očekivani režim strujanja vjetra na autocesti Sv. Rok (jug)_ $\quad$ Maslenica. Građevinar 55 (3), 149-158.

- Beltram, V., 1949: Šumski zaštitni pojas i pošumljavanje na pruge. Šumarski list br. 1-2, LXXIII, 3-15. Zagreb.

- Berbigier, P., J.M. Bonnefond, 1995: Measurement and modelling of radiation transmission within a stand of maritime pine (Pinus pinaster Ait), Ann. Sci. For. (52), 23-42.

- Brandle, J.R., L. Hodges, X.H. Zhou, 2004: Windbreaks in North American agricultural systems. Agroforestry Systems (61-62): 65-78.

- Brandle, J.R, L. Hodges, J, R.A. Tyndall Sudmeyer, 2009: Windbreak practices. American Society of Agronomy. 104 str.

- Campi P., A.D. Palumbo, M. Mastrorilli, 2009: Effects of tree windbreak on microclimate and wheat productivity in a Mediterranean environment. European Journal of Agronomy, (30): 220-227.

- Cannell, M.G.R., J. Grace, 1993: Competition for light: detections forestiers : mesure, variabilité et rôle fonctionnel Rev.For. Fr. measurement and quantification, Can. J. For. Res. (23), 19731979.

- Dostálek, J., M. Weber, T. Frantík, 2014: Establishing windbreaks: how rapidly do the smaller tree transplants reach the height of the larger ones? Journal of Forest Science, 60, (1): 1217.

- FAO (Food and Agriculture Organization of the United Nations) 1989: Arid Zone Forestry: A Guide for Field Technicians. ISBN 92-5-102809-5, Delle Terme di Caracalla, Rome, Italy.

- Farris E., G. Filibeck, M. Marignani L. Rosati, 2010: The power of potential natural vegetation (and of spatial-temporal scale): a response to Carrión \& Fernández. Journal of Biogeography, 37: 2211-2213.

- Habjanec, V., 2020: Analiza podizanja vjetrozaštitnih pojasa i nasada u Hrvatskoj. Diplomski rad, Šumarski fakultet Sveučilišta u Zagrebu. 40 str.

- Hassika, P., P. Berbigier, J.M. Bonnefons, 1997: Measurement and modelling of the phothosynthethically active radiation transmitted in a canopy of maritime pine, Ann. Sci.For. (54), 715-730. 
- Jelínek B., L. Úradníček 2010: The survival and growth rates of woody vegetation in the man-made Vracov bocorridor during the period of 1993-2007. Journal of Landscape Ecology, 3: 5-15.

- Kisić, I., S. Husnjak, M. Gajić Čapka, K. Cindrić, D. Bilandžija, B. Prekalj, 2013: Erozija tla vjetrom u Čepić polju - uzroci, posljedice i mjere ublažavanja. Hrvatske vode 21, (81), 25-38 str.

- Kisić, I., 2017: Erozija vjetrom. Hrvatske vode 25, (99), 1-12.

- Marshall, J.K., 1967: The effect of shelter on the productivity of grasslands and field crops, Field Crop Abstracts, Vol. 20.
- Rodwell J., G. Patterson, 1994: Creating New Native Woodlands. London, Forestry Commission: 74.

- Španjol, Ž., D. Barčić, M. Šango, 2019: Preporučene tehnologije i postupci, okvirni troškovnik. Izrada idejnog rješenja za podizanje vjetrobranskih nasada duž trase autoceste A1 na dionici tunel sv.Rok-Maslenica. 40 str.

- Tomašević, A., 1996: Vjetrozaštita Sinjskog polja. Šumarski list br. 1-2, CXX, 19-34. Zagreb.

- http://www.polirol.com/ (pristupljeno 17.7.2020.)

\section{SUMIMARY}

Windbreaks are established as barriers of rows of trees or shrubs that are planted to reduce wind speed, reduce evapotranspiration, protect against aeolian erosion, while being used directly to protect crops and plantations and provide favorable habitat conditions. One of the essential preconditions for the success of belt raising is the use of indigenous species that are adapted to habitat conditions. Technologies and protection procedures can be focused on biological-technical procedures of afforestation and raising plantations with the aim of mitigating wind gusts. The goal of windbreaks and raising plantations with different species is shown in the following figures (Figures 3,4,5,6,7). The choice of plant species for raising plantations is conditioned by different climatic zones, biological and ecological characteristics of the species, but also the composition with other elements of the landscape. An important feature of windbreaks is their wind permeability and impact on wind speed. Permeability depends on the habitus of the plant, and the type of trees and shrubs. The density of the windbreak changes its impact and effectiveness; the permeable belt ensures a balanced distribution as part of the wind skips it and part passes through the belt. The wind protection is placed in the direction of the main wind. Technical wind protection procedures include the construction of barriers made of building materials such as brick, stone, timber, glass, hard plastic or a combination of several types of materials (Figures 1 and 2). Biological procedures in terms of species selection and consideration of habitat conditions are much more complex. All this in the context of frequent changes in the "wind structure" in the karst area. Belt lifting can be differentiated according to purpose and expected performance as follows: impermeable belt, semi-permeable and permeable belt. The establishment of windbreaks primarily reduces wind strength and reduces its speed. In this way, the climatic extremes associated with the stormy wind are alleviated (the karst is primarily a bora) and it affects the microclimatic conditions, which can ultimately ensure the protection of agricultural and forest land.

KEY WORDS: wind, permeability, microclimate, erosion, soil protection 